
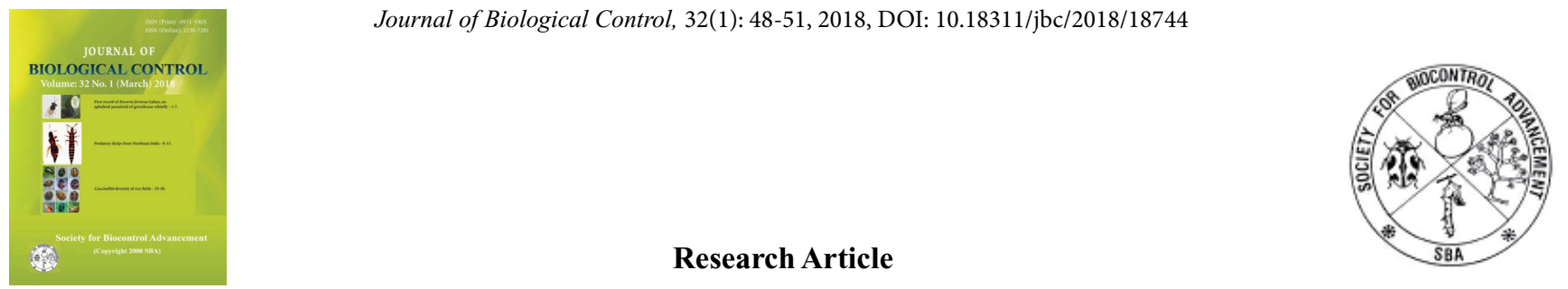

\title{
Population dynamics and new record of larval parasitoids, Senometopia sp. and Winthemia sumatrensis (Townsend) (Diptera: Tachinidae) on banana skipper, Erionota torus Evans (Lepidoptera: Hesperiidae) from South Karnataka
}

\author{
SHARANABASAPPA ${ }^{*}$ C. M. KALLESHWARASWAMY, M. S. MARUTHI and HIROSHI SHIMA ${ }^{\mathbf{1}}$ \\ Department of Entomology, College of Agriculture, University of Agricultural and Horticultural Sciences, Shivamogga - \\ 577204, Karnataka, India \\ ${ }^{1}$ Biosystematics Laboratory, Graduate School of Social and Cultural Studies, Kyushu University, Fukuoka, Japan \\ *Corresponding author E-mail: sharanu.deshmukh@gmail.com
}

\begin{abstract}
Field study was conducted for two years (2014-16) to know the population dynamics of banana skipper, Erionota torus Evans (Lepidoptera: Hesperiidae) and its tachinid parasitoids, Senometopia sp., and Winthemia sumatrensis. The pooled data over the two years indicated that the skipper plant infestation ranged from 6.66 to 84.25 per cent and incidence started during the first fortnight of August ( 8.34 per cent incidence) when the crop was at broadleaf follower stage, and a gradual increase in the infestation level of skipper was observed with a peak activity ( 84.25 per cent incidence) during first fort night of January (Pre flowering period) and also extended to the flowering period (February to March). The pooled data over the years indicated the maximum incidence was recorded during pre flowering period with a mean infestation of 75.02 per cent followed by flowering period (45.67 per cent), broad leaf followers ( 29.58 per cent) and bunch period (1.66 per cent). Two tachinid parasitoids Senometopia sp., and $W$. sumatrensis were encountered during our two years study period. The larval parasitoids activity initiated from second fortnight of September ( 0.62 per cent) and reached its maximum population during second fortnight of November ( 7.25 per cent) and later parasitoid activity gradually declined till second fortnight of January ( 0.62 per cent). The maximum activity was noticed during pre flowering period with a mean of 3.27 per cent parasitization by Senometopia sp., and W. sumatrensis.
\end{abstract}

KEY WORDS: Banana, Erionota torus, population dynamics, Senometopia sp., Winthemia sumatrensis

(Article chronicle: Received: 18-11-2017; Revised: 24-02-2018; Accepted: 15-03-2018)

\section{INTRODUCTION}

Banana (Musa sp.) is a major fruit crop believed to be originated in South-East Asia and Western pacific regions (Robinson and Sauce, 2010). Among the 470 species of insects and mites recorded globally on banana as major and minor pests of which 250 feed on the foliage cause a reduction in the total photosynthetic area (Ostmark, 1974). In India, slug caterpillars such as Latioa lepida, Miresa decadens, hairy caterpillar, Euproctis sp., Pericalia ricini, leaf beetle, Nodostoma subcostatum recorded as significant defoliators by Vevai (1971). Owing to climate change coupled with monocropping, ratooning and 'passenger distribution of pests' made some hitherto unknown pests to cause severe problems in banana cultivation especially in South India (Shivakumar et al., 2014). Among the various defoliators, Erionota torus Evans has become major folivorous pest in recent years in South India. During September 2014, E. torus outbreak was noticed in Coastal belts of Karnataka (Dakshina Kannada, Udupi and Uttar Kannada) and then spread to Malnad districts of Karnataka (Sharanabasappa et al., 2016). The larva causes considerable damage to the foliage of banana by rolling the leaf while feeding on it (Chiang and Hwang, 1991). The larvae of these butterflies can cause mean defoliation of about 60 per cent, leading to yield loss of about 20 per cent (Okolle et al., 2010). A good understanding of population dynamics of $E$. torus and its natural enemies is useful for interpreting survey data, predicting pest outbreaks and evaluating the effectiveness of management tactics. Considering the importance of this pest, there is a little information on population dynamics of this pest and associated natural enemies from India. Keeping this point in view, this study was undertaken. 


\section{MATERIALS AND METHODS}

Study was conducted during 2014-15 and 2015-16 (on ratoon crop) at Abbalagere $\left(13^{\circ} 59 \mathrm{~N}\right.$; and $75^{\circ} 35 \mathrm{E} ; 616$ MSL), Shivamogga District (Karnataka) on Ney poovan banana cultivar popularly called as Puttabale (AB) in local language. A widespread practice of growing Ney poovan as an intercrop in areca nut garden malenad and costal belts of Karnataka is there. Ney Poovan was planted in June 2014 with an area of 3 ha having a spacing of $2.4 \mathrm{~m} \mathrm{X} 2.4 \mathrm{~m}$ banana as an intercrop in 20 years old areca nut garden. All the package of practices was followed except plant protection measures. The growth stages of the Ney poovan plants were categorized as given by Okolle et al. (2006) with suitable modification. The different stages considered as narrow leaf followers (NLF - very young plants, 1-2 months old with very narrow leaves and less than $1 \mathrm{~m}$ in height), Broadleaf followers (BLF - young plants 3-7 months old, with broader leaves), Pre flowered plants (PF - plants without flowers, 7-9 months old), flowering plants (FP - plants with newly emerged flowers up to when the female phase is over, 9 to 11 months old), as bunched Plants (BP - considered as plants with new bunches up to when the bunches harvested, 11 to 12 months old).

\section{Observations}

Fifteen days after planting, observations were recorded once at fortnightly intervals till the harvest of bunches covering all phonological stages of the crop. Observations on plants infested were recorded on pest and parasitoid by observing a total of 60 plants individually from the selected field divided in four different blocks (In each block, 15 plants were selected). Plant with at least one leaf roll (one larva) in a leaf was taken as infested plant and expressed in per cent plant infestation. During each observation 20 larvae/pupae were observed in each block for parasitization. The per cent parasitization was determined from the number of infected larvae/pupae to a total number of larvae/ pupae observed. The infested larva/pupa turned to black colour with a foul smell, and such larvae were brought to the laboratory for parasitoid emergence. The mean per cent infestation was worked out at different phonological stages of the crop growth.

\section{RESULTS AND DISCUSSION}

\section{Population fluctuation of Erionota torus}

In the first year (2014-15) of the study, the infestation was recorded from August 2014 to April 2015 and the per cent plant infestation ranged from 8.33 to 91.67 . From first fortnight of August onwards, when the crop was at broad leaf followers stage, a gradual increase in the infestation level of skipper observed with a peak activity during the second fortnight of December (Pre flowering period) extended to the first fortnight of April. The maximum infestation noticed during pre-flowering and flowering period with a mean of 86.00 per cent followed by flowering period (49.16 per cent), broad leaf followers ( 38.75 per cent infestation). During narrow leaf followers (up to two months old crop) and bunch period the infestation was nil and 2.08 per cent infestation, respectively (Table 1). During 2015-16, the incidence of $E$. torus on ratoon banana crop appeared during the first fortnight of August (5 per cent infestation) and continued up to the first fortnight of April 2016. The peak population of skipper recorded during first fortnight of January 2016 ( 78.50 per cent) and then the pest population gradually declined (Table 1). The pooled data over the years indicated that pest appeared more during pre flowering period followed by flowering and broad leaf follower period with a mean per cent infestation of 75.02, 45.67 and 29.58 , respectively and there was a greater variation with respect to infestation among the different growth stages of the crop. In both the years, early stage of the crop i.e., narrow leaf follower, no infestation was noticed it may be due to the lesser height of the plant and also smaller leaf width. During bunch formation stage (11 to 12 months old crop) there was no much infestation due to the less succulent leaves and weather parameters. These results were supported by Sharanabasappa et al. (2016) who reported more infestation was recorded during pre flowering and flowering period. However, these results are in contradictory with the findings of Okolle et al. (2006) reported that more infestation was recorded during broad leaf follower stage of the crop, this may be due to change in the variety grown and climatic conditions of the region.

\section{Seasonal fluctuation of natural enemies}

Two important tachinid parasitoids Senometopia sp., and Winthemia sumatrensis were encountered during our two years study period. Senometopia sp., was ovolarviparous, laying incubated eggs on host exoskeleton. Winthemia sumatrensis was oviparous, laying unincubated eggs with hard chorion on host exoskeleton (personal communication with Shima). During 2014-15, the population of two tachinid parasitoids ranged from 1.25 to 6.25 per cent from first fortnight of October and reached its peak during second fortnight of November and declined the per cent parasitization. The peak activity noticed during the first and second fortnight of November ( 5 and 6.25 per cent). The mean maximum parasitization was recorded during pre flowering period ( 2.81 per cent) followed by broad leaf followers ( 2.03 per cent). Similarly, in 2015 - 16 the maximum of 8.25 per cent parasitization recorded during second fortnight of November 2015. Compared to previous year the per cent parasitization was more during the second year. 
Table 1. Population dynamics of Erionota torus and its natural enemies on banana cv. Ney pooven or Puttabale (AB) as an intercrop in arecanut in Shivamogga district during 2014-15 and 2015-16

\begin{tabular}{|c|c|c|c|c|c|c|c|c|c|}
\hline \multirow[t]{2}{*}{ Months } & \multirow[t]{2}{*}{$\begin{array}{l}\text { Stage of the } \\
\text { crop }\end{array}$} & \multicolumn{3}{|c|}{$\%$ infestation of plant } & \multicolumn{2}{|c|}{ Stage of the pest } & \multicolumn{3}{|c|}{$\begin{array}{l}\text { Per cent parasitization by } \\
\text { Senometopia } \mathrm{sp} / W \text {. sumatrensis }\end{array}$} \\
\hline & & $2014-15$ & $2015-16$ & Pooled & $2014-15$ & $2015-16$ & $2014-15$ & $2015-16$ & Pooled \\
\hline I FN June & \multirow{4}{*}{$\begin{array}{l}\text { Narrow leaf } \\
\text { period ( } 1 \text { to } 2 \\
\text { months ) }\end{array}$} & 0.00 & 0.00 & 0.00 & 0.00 & 0.00 & 0.00 & 0.00 & 0.00 \\
\hline II FN June & & 0.00 & 0.00 & 0.00 & 0.00 & 0.00 & 0.00 & 0.00 & 0.00 \\
\hline I FN July & & 0.00 & 0.00 & 0.00 & 0.00 & 0.00 & 0.00 & 0.00 & 0.00 \\
\hline II FN July & & 0.00 & 0.00 & 0.00 & 0.00 & 0.00 & 0.00 & 0.00 & 0.00 \\
\hline Mean & & 0.00 & 0.00 & 0.00 & 0.00 & 0.00 & 0.00 & 0.00 & 0.00 \\
\hline I FN August & \multirow{8}{*}{$\begin{array}{l}\text { Broad leaf } \\
\text { followers ( } 3 \\
\text { to } 7 \text { months) }\end{array}$} & 11.67 & 5.00 & 8.34 & $\mathrm{E}, \mathrm{L}$ & E, L & 0.00 & 0.00 & 0.00 \\
\hline II FN August & & 16.67 & 6.67 & 11.67 & E, L, P & E, L, P & 0.00 & 0.00 & 0.00 \\
\hline I FN September & & 23.33 & 8.33 & 15.83 & $\mathrm{E}, \mathrm{L}, \mathrm{P}, \mathrm{A}$ & $\mathrm{E}, \mathrm{L}, \mathrm{P}, \mathrm{A}$ & 0.00 & 0.00 & 0.00 \\
\hline II FN September & & 30.00 & 16.67 & 23.34 & $\mathrm{E}, \mathrm{L}, \mathrm{P}, \mathrm{A}$ & E, L, P, A & 0.00 & 1.25 & 0.62 \\
\hline I FN October & & 41.67 & 20.00 & 30.84 & $\mathrm{E}, \mathrm{L}, \mathrm{P}, \mathrm{A}$ & E, L, P, A & 1.25 & 2.50 & 1.87 \\
\hline II FN October & & 50.00 & 31.67 & 40.84 & $\mathrm{E}, \mathrm{L}, \mathrm{P}, \mathrm{A}$ & E, L, P, A & 3.75 & 3.75 & 3.75 \\
\hline I FN November & & 65.00 & 35.00 & 50.00 & E, L, P, A & E, L, P, A & 5.00 & 7.50 & 6.25 \\
\hline II FN November & & 71.67 & 40.00 & 55.84 & E, L, P, A & E, L, P, A & 6.25 & 8.25 & 7.25 \\
\hline Mean & & 38.75 & 20.41 & 29.58 & & & 2.03 & 2.90 & 2.46 \\
\hline I FN December & \multirow{4}{*}{$\begin{array}{l}\text { Pre flowering } \\
\text { period ( } 7 \text { to } 9 \\
\text { months) }\end{array}$} & 81.67 & 43.33 & 62.50 & $\mathrm{E}, \mathrm{L}, \mathrm{P}, \mathrm{A}$ & $\mathrm{E}, \mathrm{L}, \mathrm{P}, \mathrm{A}$ & 5.00 & 6.25 & 5.62 \\
\hline II FN December & & 91.67 & 56.67 & 74.17 & E, L, P, A & $\mathrm{E}, \mathrm{L}, \mathrm{P}, \mathrm{A}$ & 3.75 & 5.00 & 4.37 \\
\hline I FN January & & 90.00 & 78.50 & 84.25 & $\mathrm{E}, \mathrm{L}, \mathrm{P}, \mathrm{A}$ & $\mathrm{E}, \mathrm{L}, \mathrm{P}, \mathrm{A}$ & 1.25 & 3.75 & 2.50 \\
\hline II FN January & & 80.67 & 76.67 & 79.17 & E, L, P, A & $\mathrm{E}, \mathrm{L}, \mathrm{P}, \mathrm{A}$ & 1.25 & 0.00 & 0.62 \\
\hline Mean & & 86.00 & 63.79 & 75.02 & & & 2.81 & 3.75 & 3.27 \\
\hline I FN February & \multirow{4}{*}{$\begin{array}{l}\text { Flowering } \\
\text { period ( } 9 \text { to } \\
11 \text { months) }\end{array}$} & 80.00 & 73.33 & 76.66 & $\mathrm{E}, \mathrm{L}, \mathrm{P}, \mathrm{A}$ & $\mathrm{E}, \mathrm{L}, \mathrm{P}, \mathrm{A}$ & 0.00 & 0.00 & 0.00 \\
\hline II FN February & & 66.67 & 58.33 & 62.50 & $\mathrm{~L}, \mathrm{P}, \mathrm{A}$ & $\mathrm{L}, \mathrm{P}, \mathrm{A}$ & 0.00 & 0.00 & 0.00 \\
\hline I FN March & & 38.33 & 26.67 & 32.50 & $\mathrm{~L}, \mathrm{P}, \mathrm{A}$ & $\mathrm{L}, \mathrm{P}, \mathrm{A}$ & 0.00 & 0.00 & 0.00 \\
\hline II FN March & & 11.67 & 10.00 & 10.83 & $\mathrm{~L}, \mathrm{P}, \mathrm{A}$ & $\mathrm{L}, \mathrm{P}, \mathrm{A}$ & 0.00 & 0.00 & 0.00 \\
\hline Mean & & 49.16 & 42.08 & 45.67 & & & 0.00 & 0.00 & 0.00 \\
\hline I FN April & \multirow{4}{*}{$\begin{array}{l}\text { Bunch Plants } \\
\text { (11 to } 12 \\
\text { months) }\end{array}$} & 8.33 & 5.00 & 6.66 & $\mathrm{~L}, \mathrm{P}, \mathrm{A}$ & $\mathrm{L}, \mathrm{P}, \mathrm{A}$ & 0.00 & 0.00 & 0.00 \\
\hline II FN April & & 0.00 & 0.00 & 0.00 & $\mathrm{P}$ & $\mathrm{P}$ & 0.00 & 0.00 & 0.00 \\
\hline I FN May & & 0.00 & 0.00 & 0.00 & 0.00 & 0.00 & 0.00 & 0.00 & 0.00 \\
\hline II FN May & & 0.00 & 0.00 & 0.00 & 0.00 & 0.00 & 0.00 & 0.00 & 0.00 \\
\hline Mean & & 2.08 & 1.25 & 1.66 & 0.00 & 0.00 & 0.00 & 0.00 & 0.00 \\
\hline
\end{tabular}

E - Egg, L - Larva, P - Pupa and A - Adult

The analysis of the pooled data revealed that the parasitoid activity more during pre flowering ( 3.27 per cent parasitization) and broad leaf followers ( 2.46 per cent parasitization) period only. This is the first report from India for tachinid parasitoids on the banana skipper, E. torus (Table 1).

These results confirm to the findings of Shima (1996), $W$. sumatrensis is common on E. torus host in the Oriental Region and Japan. In both the years, the parasitization was not crossed the ten per cent this was due to mainly predation by the birds like, crow pheasant (Centropus sinensis) and house crow (Corvus splendens) found to feeding on fourth and fifth instar Erionota larvae. We don't have earlier reports to compare and discuss the present results of these tachinids attacking E. torus. However, Soumya et al. (2013) recorded the more parasitization of unidentified tachinid parasitoid on E. torus during September, may be due to variety grown and climatic conditions of that region. Bhumannavar and Viraktamath (2001) recorded the tachinid; Winthemia sp. parasitized only the fifth instar of Othreis materna. Winthemia sp. lay eggs on the lateral side of the prothorax and on hatching the maggots directly entered the host body by cutting the skin just below the egg attachment. The maggot development continued until the host caterpillar pupated. Full-grown larvae came out from the host pupa through a hole and pupated either in soil or leaf debris. The studies concerning biology of these parasitoids and mass multiplication are in progress.

\section{ACKNOWLEDGEMENTS}

We would like to thank the Director of Research, UAHS, Shivamogga for providing the financial support. The authors are also grateful to Dr. Hiroshi Shima, Chuo- 
Population dynamics and new record of larval parasitoids, Senometopia sp. and Winthemia sumatrensis on banana skipper

ku, Fukuoka, Japan for identifying the tachinid parasitoids.

\section{REFERENCES}

Bhumannavar BS, Viraktamath CA. 2001. Seasonal incidence and extent of parasitization of fruit piercing moths of the genus Othreis (Lepidoptera: Noctuidae). J Biol Control 15:31-38.

Chiang HS, Hwang MT. 1991. The banana skipper, Erionota torus (Hesperiidae: Lepidoptera): establishment, distribution, and extent of damage in Taiwan. Tropical Pest Mgmt. 37: 207-210. https://doi. org/10.1080/09670879109371583

Okolle JN, Mashor M, Ahmad AH. 2006. Spatial distribution of banana skipper (Erionota thrax L.) (Lepidoptera: Hesperiidae) and its parasitoids in a Cavendish banana plantation, Penang, Malaysia. Insect Sci. 13:381-389. https://doi.org/10.1111/j.1744-7917.2006.00107.x

Okolle JN, Ahmad AH, Mansor M. 2010. Bioecology and management of the banana skipper (Erionota thrax). Tree and For Sci and Biotech. 4: 22-31.

Ostmark HE. 1974. Economic insect pests of banana. Annu Rev Entomol. 19:161-176. https://doi.org/10.1146/ annurev.en.19.010174.001113
Robinson JC, Sauce VG. 2010. Bananas and Plantains. 2nd Ed. CAB International. pp. 312. https://doi. org/10.1079/9781845936587.0000 PMid:20557503

Sharanabasappa, Kalleshwaraswamy CM, Adivappar N, Lavanya MN. 2016. Population dynamics and natural enemies of Erionota torus Evans (Lepidoptera: Hesperiidae) on two cultivars of banana in Karnataka. Pest Mgmt Hort Ecosyst. 22: 34-39.

Shima H. 1996. A systematic study of the tribe Winthemiini from Japan (Diptera: Tachinidae). Beitr Ent. 46: 169-235.

Sivakumar T, Jiji T, Anitha N. 2014. Field observations on banana skipper Erionota thrax L. (Hesperiidae: Lepidoptera) and its avian predators from southern peninsular India. Current Biotica 8(3): 220-227.

Soumya KC, Sajeev TV, Maneetha, TK, Vijayan K, Mathew G. 2013. The incidence of Erionota thrax (Hübner) (Lepidoptera: Hesperiidae) as a pest of banana in Kerala. Entomon 38: 53-58.

Vevai EJ. 1971. Know your crop, its pest problems, and control. Pesticides 5: 38-56. 